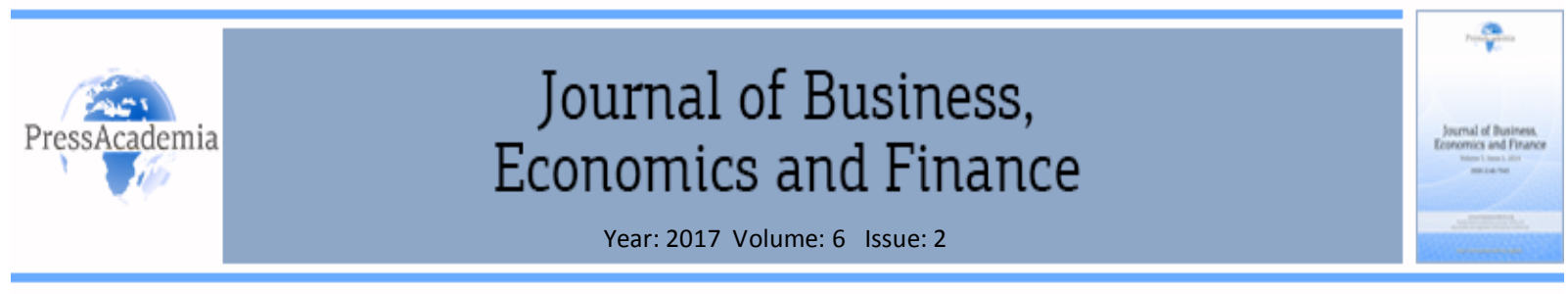

\title{
INNOVATION IN FINANCIAL MARKETS AND ITS IMPACT ON SAVINGS
}

\author{
DOI: 10.17261/Pressacademia.2017.504 \\ JBEF- V.6-ISS.2-2017(10)-p.147-154
}

\author{
Tarana Azimova ${ }^{1}$, Ebubekir Mollaahmetoglu ${ }^{2}$ \\ ${ }^{1}$ Khazar University, Baku, Azerbaijan. teraneazimli@gmail.com \\ ${ }^{2}$ Istanbul University, Istanbul, Turkey. ebubekirm@istanbul.edu.tr
}

\section{To cite this document}

Azimova T. and E. Mollaahmetoglu (2017). Innovation in financial markets and its impact on savings . Journal of Business, Economics and Finance (JBEF), V.6, Iss.2, p.147-154.

Permemant link to this document: $\mathrm{http}: / /$ doi.org/10.17261/Pressacademia.2017.504

Copyright: Published by PressAcademia and limited licenced re-use rights only

\begin{abstract}
Purpose- Financial innovation augment the investment alternatives of individuals, allowing them to have different investment opportunities in changing economic conditions. Channeling the idle savings into productive sectors increase the fund margin of households and entrepreneurs facing financial squezee. The aim of this paper to examine the impact of financial services on savings and domestic savings. The paper analyzes the main determinants of savings in twenty upper middle income, high income countries for the period of 2005-2014.

Methodology- In this paper, we build panel data analyses to investigate the impact of innovation in financial markets on savings and domestic savings.

Findings- Level of financial innovation and financial access are important parameters affecting both gross savings and gross domestic savings. higher financial innovation leads to higher savings and domestic savings. The net interest margin and banking crisis has a negative effect on savings in both models. Increase in capital formation contribute to higher gross savings and gross domestic savings.

Conclusion- The paper finds that financial innovation and diversification is an important lever in the increasing of savings, therefore confirming the "liberalization of financial market" hypothesis.
\end{abstract}

Keywords : Financial innovation, Savings, Financial diversification and access, Panel data analyses

JEL Codes: E21, G2, P34

\section{INTRODUCTION}

Financial innovation is measured by advance in the financial products, which are employed in the borrowing and lending of funds. These variations in financial technology have given financial institutions modern and inexpensive ways to obtain resources and augmented existing credit lines for customers. Therefore, financial innovation provide an efficient movement and allocation of economic resources across time and among a number of investors and financial institutions. These changes, in turn, positively affects household savings who allocate funds for the purposes of smoothing consumptions and protection against unexpected future events. A great variety of financial innovation that became part of a new financial production process has been introduced into the financial markets in recent years. The most recent innovations in the financial markets are financial products such as derivatives; financial services such as internet banking, mobile banking, and online trading; financial technology such as Automated Teller Machines (ATMs). New financial instruments developed to better satisfy financial system participants' demands. From this point of view, a financial 
innovation symbolizes a new financial service or financial asset that decrease risks, diminish costs and provide services that are more efficient for customers.

This paper will proceed as follows. In Section II we provide theoretical background on financial innovation and savings; Section III provides the available empirical works on financial innovation Section IV describes the data and statistical approach; Section $\mathrm{V}$ provides empirical results and findings.

\section{THEORETICAL BACKGROUND}

McKinnon and Shaw (1973) put forward the financial repression hypothesis, used to express every kind of control and intervention in the financial system during economic crises of the 1970s. Supporters of the theory of financial repression, which provide the basis for financial liberalization, criticized restriction of interest. They emphasized that the liberalization of capital flows, interest rates, and credit facilities will increase effective resource allocation and savings and this in turn will transform into investments. These changes will promote economic growth. Liberalization lead to increase in the number of new instruments used in the financial markets, this process mobilize savings and, economic growth realized through provision of financial development. In other words, the existence of diversified market will increase the efficient movement of fund, therefore increasing savings and eventually promoting the growth. The target of liberalization policies and financial development across financial markets is to channel financial resources from informal financial markets to formal financial markets. The downward pressure on interest rates promotes transfer of idle funds and internal savings to the financial sector and therefore eliminate saving gaps. (Shaw, 1973)

One of the most important implications of financial deregulation is indeed to increase openness to financial innovation and market diversification. Because not only technological innovation contributes to cost deduction but it also leads to product efficiency and new market opportunities. According to the Oslo Manual; innovation is classified as product innovation, process innovation, organizational innovation and marketing innovation. Marketing innovation defines as "Implementation of a new marketing method involving significant changes in product design or packaging, product placement, product promotion or pricing" (Saldanli \& Seker, 2013-38). The augmented intensity of competition in the financial sector has had direct impact on banks' approach to clients. Investors in the financial markets pursue the target of profit maximization. Their decisions and behaviors are not coherent and subject to great variations accross time. (Kıyılar \& Akkaya, 2016-1). The banks are competing fiercely in the financial markets to satisfy the needs of these clients. This competition has direct implications in achieving competitive advantage through technological innovation. Rising awareness of importance of financial innovation in modern economies has increased research interest in this field. In fact, a broad theoretical information that discusses latest financial innovations has arisen. However, the absence of patent data in the financial sector impose limitations on conducting a quantitative cross-country analysis in this field. To fill this gap we therefore use data on R\&D expenditure as proxy of a financial innovation. We obtain these data from Analytical Business Enterprise Research and Development database (ANBERD) of the OECD.

Figure 1: Financial Innovation (Financial R\&D) Across Countries, Averaged 2005 To 2014.

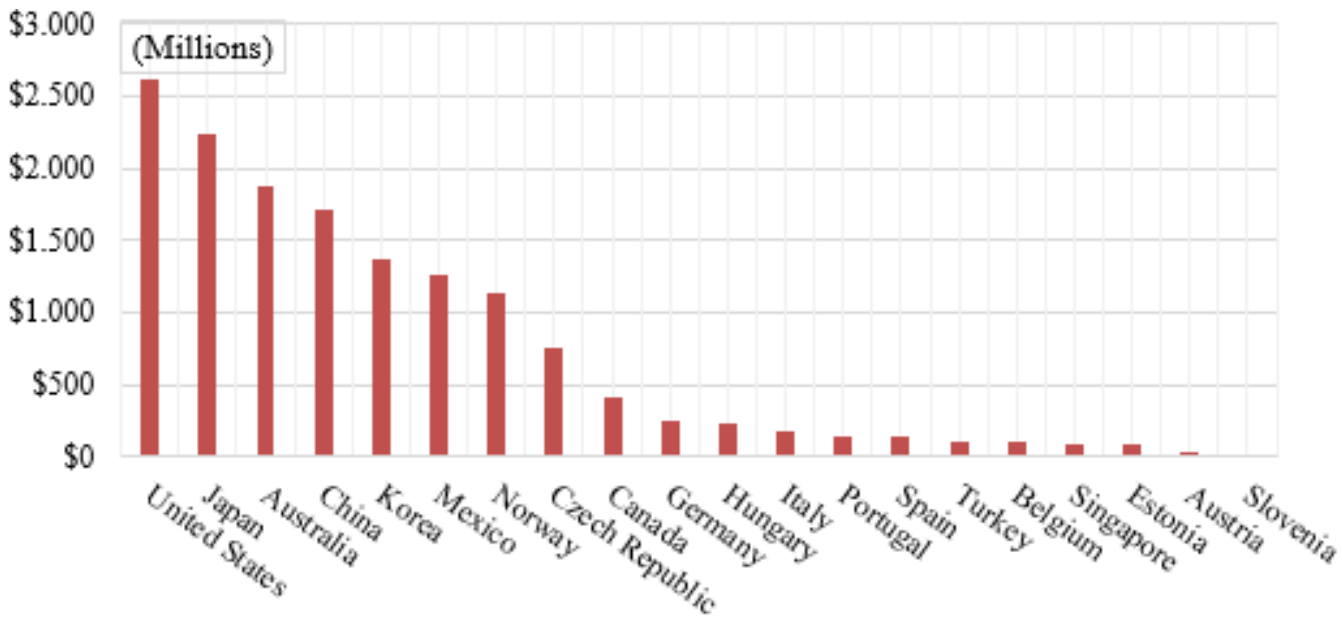

Sources: Analytical Business Enterprise Research and Development Database (ANBERD), (Online), Access date: March 01, 2017, http://www.oecd.org/ 
Observing research and development figures across countries, we find broad variation on financial R\&D figures across countries ranging from high levels in United States, Japan and Australia to very negligent expenditures in Austria and Slovenia. Surprisingly enough, the upper middle-income countries such as Turkey and Hungary spend on financial R\&D more than some high income: countries such as Singapore and Belgium.

Figure 2: Financial Innovation (Financial R\&D) Across Time and Across Countries, 2005 To 2014.

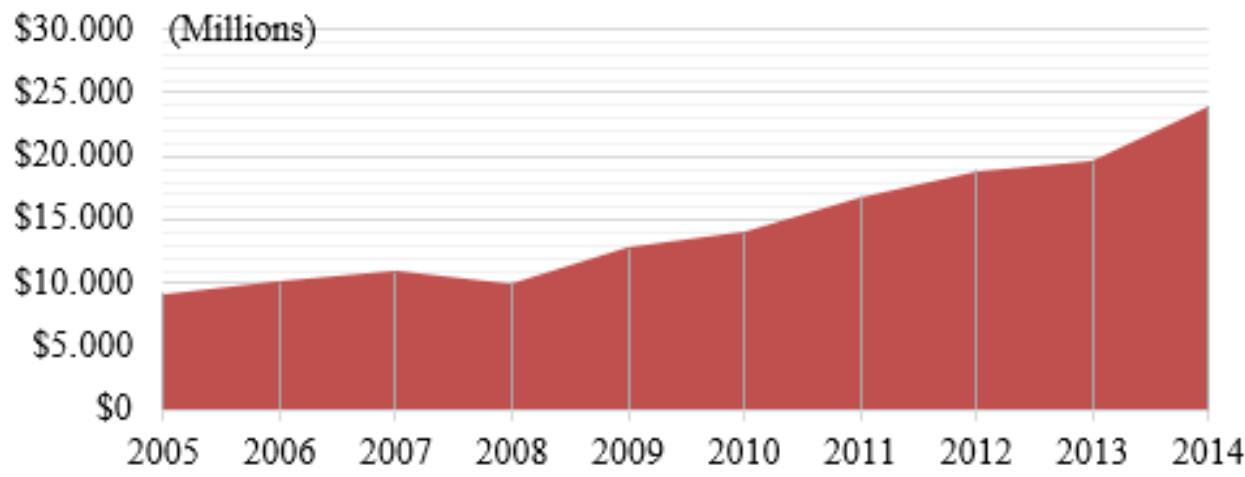

Sources: Analytical Business Enterprise Research and Development Database (ANBERD), (Online), Access date: March 01, 2017, http://www.oecd.org/

Looking at graphical representation of financial R\&D figures, we note an increasing trend in expenditures over time across our sample countries. However, financial R\&D expenditures decreased by 8 percent during financial crisis of 2008. Financial innovation has increased by more than 2 times between 2005 and 2014 indicating on widening of financial system.

\section{LITERATURE REVIEW}

The Table 1 below provides information on literature review.

Table 1: Summary of Literature Review Table

\begin{tabular}{|c|c|c|c|c|}
\hline Author & Sample & Title & Source & Findings \\
\hline $\begin{array}{l}\text { Josh Lerner } \\
(2002)\end{array}$ & $\begin{array}{l}\text { Financial patents (1971- } \\
\text { 2000) }\end{array}$ & $\begin{array}{l}\text { Where Does State } \\
\text { Street Lead? A First } \\
\text { Look at Finance } \\
\text { Patents }\end{array}$ & $\begin{array}{l}\text { Journal of } \\
\text { Finance }\end{array}$ & $\begin{array}{l}\text { The results show that the patenting } \\
\text { activity of investment banks is } \\
\text { positively related to the size of the } \\
\text { investment banks }\end{array}$ \\
\hline $\begin{array}{l}\text { Elizabeth } \\
\text { Laderman (1990) }\end{array}$ & $\begin{array}{l}\text { State by state analysis of } \\
\text { a number of ATM cards } \\
\text { and ATMs in use }\end{array}$ & $\begin{array}{l}\text { The Public Policy } \\
\text { Implications of State } \\
\text { Laws Pertaining to } \\
\text { Automated Teller } \\
\text { Machines. }\end{array}$ & $\begin{array}{l}\text { Economic } \\
\text { Review, } \\
\text { Federal } \\
\text { Reserve } \\
\text { Bank of SF }\end{array}$ & $\begin{array}{l}\text { The number of ATM cards in use per } \\
\text { state, as of } 1987 \text {, is significantly and } \\
\text { positively related to population and } \\
\text { per capita income and negatively } \\
\text { related to the number of branches. }\end{array}$ \\
\hline $\begin{array}{l}\text { Patrick Honohan } \\
(2006)\end{array}$ & $\begin{array}{l}\text { Financial access by } \\
\text { households to financial } \\
\text { assets, presenting data } \\
\text { for over } 150 \text { countries }\end{array}$ & $\begin{array}{l}\text { Hosehold Financial } \\
\text { Assest in the Process } \\
\text { of Development }\end{array}$ & World Bank & $\begin{array}{l}\text { Financial access is negatively } \\
\text { correlated with poverty rates, but the } \\
\text { correlation is not a robust one. }\end{array}$ \\
\hline $\begin{array}{l}\text { Hannig and } \\
\text { Jansen(2010) }\end{array}$ & $\begin{array}{l}\text { Policy examples across } \\
\text { countries }\end{array}$ & $\begin{array}{l}\text { Financial Inclusion } \\
\text { and Financial } \\
\text { Stability: Current } \\
\text { Policy Issues }\end{array}$ & $\mathrm{ADBI}$ & $\begin{array}{l}\text { Innovations aimed at countering } \\
\text { financial exclusion may help } \\
\text { strengthen financial systems rather } \\
\text { than weakening them. }\end{array}$ \\
\hline
\end{tabular}


The bank-, industry- and Tao Chen, Chen Lin and Frank M. Song (2012) Santiago Carbó Valverde, Rafael López del Paso and Francisco Rodríguez Fernández (2011) country-level data for and 2006 32, mostly high-income, Financial Innovation: HKIMR countries between 1996 The Bright and Dark Working Sides Paper

\section{7 administrative} regions of Spain over the Financial period 1986- 2001 Innovations In summing up to 272 Banking: Impact on panel observations. Regional Growth
University of Granada, contribute positively to regional GDP, Spain investment and gross savings growth.
Financial innovation is increased with higher growth volatility among industries more dependent on external funding and with higher idiosyncratic bank fragility, higher bank profit volatility and higher bank losses.

The results show that product and

\section{DATA AND METHODOLOGY}

The sample covers annual data from 2005 to 2014 for a sample of 20 high-income and upper-income economies. The time span is constrained by the scarcity of financial innovation and financial services time series for individual countries. The Table 2 summarizes all variables and their sources.

Table 2: The Variables Used in Models

\begin{tabular}{|c|c|c|c|c|c|}
\hline \multirow[b]{2}{*}{ Variables } & \multicolumn{2}{|r|}{ MODEL 1} & \multicolumn{2}{|r|}{ MODEL 2} & \multirow[b]{2}{*}{ Sources } \\
\hline & \begin{tabular}{|l|} 
Acronym \\
\end{tabular} & Description & \begin{tabular}{|l|} 
Acronym \\
\end{tabular} & Description & \\
\hline Dependent & Gsav & $\begin{array}{l}\text { Gross Savings (\% of } \\
\text { GDP) })^{1}\end{array}$ & GDsav & $\begin{array}{l}\text { Gross Domestic } \\
\text { Savings (\% of GDP) }\end{array}$ & $\begin{array}{l}\text { World Bank, Development } \\
\text { Indicators } \\
\text { (www.worldbank.org) }\end{array}$ \\
\hline \multirow{4}{*}{ Independent } & FInov & $\begin{array}{l}\text { Financial Innovation } \\
\text { (Financial R\&D) / GDP }\end{array}$ & FInov & \begin{tabular}{|l} 
Financial Innovation \\
(Financial R\&D)/ GDP
\end{tabular} & $\begin{array}{c}\text { Analytical Business } \\
\text { Enterprise Research and } \\
\text { Development database } \\
\text { (www.oecd.org) }\end{array}$ \\
\hline & ATMKm & $\begin{array}{l}\text { Automated Teller } \\
\text { Machines (ATMs) per } \\
1,000 \mathrm{~km} 2\end{array}$ & ATMPa & $\begin{array}{l}\text { Automated Teller } \\
\text { Machines (ATMs) per } \\
\text { 100,000 adults }\end{array}$ & \multirow{2}{*}{$\begin{array}{c}\text { International Monetary } \\
\text { Fund, Financial Acces Survey } \\
\text { Dataset (www.imf.org) }\end{array}$} \\
\hline & BanKm & $\begin{array}{l}\text { Branches of banks per } \\
1,000 \mathrm{~km} 2\end{array}$ & \multirow[t]{2}{*}{ BanPa } & \multirow[t]{2}{*}{$\begin{array}{l}\text { Branches of banks } \\
\text { per } 100,000 \text { adults }\end{array}$} & \\
\hline & $\mathrm{N} \ln M$ & $\begin{array}{l}\text { Bank Net Interest } \\
\text { Margin (\%) }\end{array}$ & & & \multirow{2}{*}{$\begin{array}{l}\text { World Bank, Global Financial } \\
\text { Development Database } \\
\text { (www.worldbank.org) }\end{array}$} \\
\hline Dummy & $\mathrm{BCr}$ & $\begin{array}{l}\text { Banking Crisis Dummy } \\
\text { (1=Banking crisis, } \\
0=\text { None) }\end{array}$ & $\mathrm{BCr}$ & $\begin{array}{l}\text { Banking Crisis } \\
\text { Dummy (1=Banking } \\
\text { crisis, } 0=\text { None) } \\
\end{array}$ & \\
\hline Explanatory & CapF & $\begin{array}{l}\text { Gross capital } \\
\text { formation (\% of GDP) }\end{array}$ & CapF & $\begin{array}{l}\text { Gross capital } \\
\text { formation (\% of GDP) }\end{array}$ & $\begin{array}{l}\text { World Bank, World } \\
\text { Development Indicators } \\
\text { (www.worldbank.org) }\end{array}$ \\
\hline
\end{tabular}

\footnotetext{
${ }^{1}$ Gross domestic savings are calculated as GDP less final consumption expenditure (total consumption).

${ }^{2}$ Gross savings are calculated as gross national income less total consumption, plus net transfers.
} 
The panel data analysis employed to predict the impact of financial services on savings and domestic savings. The use of panel technique provides the benefit of rising the sample size while obtaining a cross-country perspective. A panel data regression differs from a regular time-series or cross-section regression in that it has a double subscript on its variables. (Tatoglu 2012: 37)

$$
Y_{i t}=\beta_{0 i t}+\beta_{1 i t} X_{1 i t}+\beta_{2 i t} X_{2 i t}+\ldots+\beta_{k i t} X_{k i t}+u_{i t} \quad i=1, \ldots, N \quad t=1, \ldots, T
$$

or

$$
Y_{\mathrm{it}}=\beta_{\mathrm{Oit}}+\sum_{\mathrm{k}=1}^{\mathrm{K}} \beta_{\mathrm{kit}} \mathrm{X}_{\mathrm{kit}}+\mathrm{u}_{\mathrm{it}} \quad \mathrm{i}=1, \ldots, \mathrm{N} \quad \mathrm{t}=1, \ldots, \mathrm{T}
$$

The subscript $\mathrm{i}$ denotes the cross-section dimension and $\mathrm{t}$ denotes the time-series dimension with different frequencies. Panel data encompasses several different linear models such as pooled OLS, fixed-effects and random-effects models. After running the tests to predict time and individual effects, it is important to make a clear distinction between the models (Tatoglu 2012: 37). Therefore, in this paper we employed a Hausman test to make a chose between fixed-effects and random-effects models.

Table 3: Individual and/or Time Effects Test Results

\begin{tabular}{lcccc}
\hline \multicolumn{5}{c}{ Model 1 } \\
\hline Tests & $\begin{array}{c}\text { LR Test for Indv. And } \\
\text { Time Effects }\end{array}$ & LR for Ind. & LR for Time. & F Test for Fixed Effects \\
\hline Prob. & $(0.0000)$ & $(0.0000)$ & $(1.000)$ & $(0.0000)$ \\
\hline Individual Effect & Yes & Yes & - & Yes \\
\hline Time Effect & Yes & - & No & - \\
\hline \multicolumn{7}{l}{} & & & Model 2 & \\
\hline Tests & LR Test & LR for Ind. & LR for Time. & F Test for Fixed Effects \\
\hline Prob. & $(0.0000)$ & $(0.0000)$ & (1.000) & $(0.0000)$ \\
\hline Individual Effect & Yes & Yes & - & Yes \\
\hline Time Effect & Yes & - & No & - \\
\hline
\end{tabular}

According to LR Test result in the first column there is individual or time effects for both models. LR test also separately retest the time and individual effects; so second column shows that there is individual effect and third column test result shows that there is no time effect. Besides, $\mathrm{F}$ test reveals that individual effect exists in the models.

Table 4: Hausman Test for Random or Fixed Effects

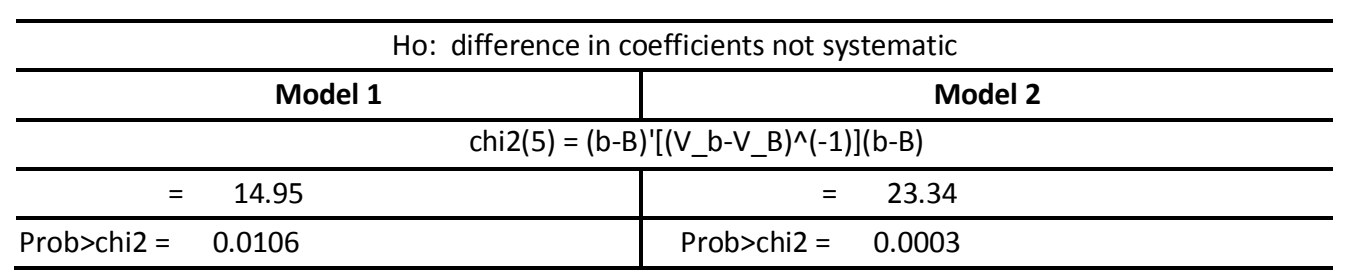

The probability is 0.0106 for model 1 and 0.0003 for model 2 , both of them are less than 0.05 , so reject the null hypothesis that individual effect are random. According to the Hausman test result, all models should be estimated by using the fixed effects and determined one-way error component regression model shown by equation (3) below (Hausman 1978: 12511271).

$$
Y_{i t}=\beta_{0}+\mu_{i}+\beta_{1} X_{1 i t}+\beta_{2} X_{2 i t}+\ldots+\beta_{k} X_{k i t}+u_{i t} \quad i=1, \ldots, N \quad t=1, \ldots, T
$$

Then we tested the assumption of heteroscedasticity, autocorrelation and cross-sectional dependence. 


\section{Table 5: Test for Heteroscedasticity}

\begin{tabular}{c|c}
\hline H0: sigma(i)^2 $=$ sigma^2 for all $\mathrm{i}^{\wedge}$ \\
\hline Model $\mathbf{1}$ & Model $\mathbf{2}$ \\
\hline chi2 $(20)=1532.62$ & chi2 $(20)=2017.16$ \\
\hline Prob>chi2 $=0.0000$ & Prob $>$ chi2 $=0.0000$ \\
\hline
\end{tabular}

Probabilities in both of models are less than 0.05 , so reject the null hypothesis homoskedasticity and conclude heteroskedasticity.

\section{Table 6: Test for Serial Correlation}

HO: No AR(1)) in the following specification for the error terms $A R(1)$ disturbances

\begin{tabular}{l}
\hline \\
\hline F test that all $u \_i=0: \quad F(19,154)=5.97 \quad$ Prob $>F=0.0000$ \\
\hline Modified Bhargava et al. Durbin-Watson $=.60065146$ \\
\hline Baltagi-Wu LBI $=.9557007$ \\
\hline F test that all $u \_i=0: \quad F(19,155)=6.49 \quad$ Prob $>F=0.0000$ \\
\hline Modified Bhargava et al. Durbin-Watson $=.57636599$ \\
\hline Baltagi-Wu LBI $=.94314423$
\end{tabular}

DW and Baltagi-Wu LBI test statistics reject the null hypothesis of no first-order serial correlation for Model 1 and Model 2. Besides; DW critical values; $\mathrm{d}<2$ shows positive serial correlation.

Table 7: Test for Cross Sectional Dependency

\begin{tabular}{|c|c|c|}
\hline & \multicolumn{2}{|c|}{ Tests for Cross Sectional Independence } \\
\hline & Model 1 & Model 2 \\
\hline Pesaran's test & $12.441 \operatorname{prob}(0.0000)$ & $13.554 \operatorname{prob}(0.0000)$ \\
\hline Friedman's test & $51.240 \operatorname{prob}(0.0001)$ & $62.553 \operatorname{prob}(0.0000)$ \\
\hline Frees' test & 2.048 Critical Value $<$ alpha $=0.05: 0.3429$ & 2.201 Critical Value $<$ alpha $=0.05: 0.3429$ \\
\hline
\end{tabular}

Pesaran's and Friedman's test strongly rejects the null hypothesis of no cross-sectional dependence at the $1 \%$ level of significance. Frees' test also reject null hypothesis. Three test results for both models conclude enough evidence to reject the null hypothesis of cross-sectional independence. In accordance with the test results from Stata, using xtscc command, all models are assumed to be heteroskedastic, autocorrelated, and possibly correlated between the groups. Therefore, Driscoll and Kraay standard errors are appropriate for both models. 
Table 8: Fixed-Effect (Within) Regression With Driscoll And Kraay Standard Errors

\begin{tabular}{|c|c|c|c|}
\hline \multicolumn{2}{|c|}{ MODEL 1} & \multicolumn{2}{|c|}{ MODEL 2} \\
\hline \multicolumn{2}{|c|}{ Gross Savings (\% of GDP) } & \multicolumn{2}{|c|}{ Gross Domestic Savings (\% of GDP) } \\
\hline \multirow{2}{*}{ FInov } & $0.2577^{* *}$ & FInov & $0.2708^{* *}$ \\
\hline & $(0.0981)$ & & (0.0979) \\
\hline \multirow[t]{2}{*}{ ATMKm } & $0.0031^{* *}$ & ATMPa & $-0.0441^{* * *}$ \\
\hline & $(0.0013)$ & & (0.0139) \\
\hline \multirow[t]{2}{*}{ BanKm } & $-0.000 * *$ & & \\
\hline & & BanPa & $(0018)$ \\
\hline \multirow[t]{2}{*}{ NInM } & $-0.4616^{* *}$ & & \\
\hline & $(0.2136)$ & & \\
\hline \multirow[t]{2}{*}{$\mathrm{BCr}$} & $0.0256^{* *}$ & $\mathrm{BCr}$ & $0.0264 * *$ \\
\hline & & & $(0.0091)$ \\
\hline \multirow[t]{2}{*}{ CapF } & $0.0044^{* * *}$ & CapF & $0.0050 * * *$ \\
\hline & $(0.0008)$ & & $(0.0006)$ \\
\hline \multirow[t]{2}{*}{ Constant } & $0.1446^{* * *}$ & Constant & $0.1367 * * *$ \\
\hline & $(0.0317)$ & & $(0.0232)$ \\
\hline \multirow[t]{2}{*}{ F Test $(6,19)$} & 31.84 & F Test (5.19) & 22.92 \\
\hline & $(0.0000)^{* * *}$ & & $(0.0000)^{* * *}$ \\
\hline \multirow{2}{*}{$\begin{array}{l}\text { Number of Obs / } \\
\text { Groups }\end{array}$} & $200 / 20$ & Number of Obs / & $200 / 20$ \\
\hline & & Groups & \\
\hline R-squared & 0.1408 & R-squared & 0.1775 \\
\hline
\end{tabular}

\section{FINDINGS AND DISCUSSIONS}

We estimate a fixed effect model to analyze the interaction among variables. Only statistically significant factors are interpolated in the fixed panel regression model. We construct two different models and examine the impact of different factors on gross savings and gross domestic savings. The overall regression results are significant at 5 percent significance level, but explanatory powers are somewhat low. In model 2 we manage to increase the explanatory power of the test.

Model 1: Gsav $=0.1446599+0.2577305$ FInov + 0.0031658ATMKm $-0.000546 B a n K m-0.4616618 \mathrm{NInM}$

$$
+0.0256333 \mathrm{BCr}+0.0044975 \mathrm{CapF}
$$

Model 2: GDsav $=0.1367312+0.2708968$ FInov $-0.0441432 A T M P a+0.0145647 B a n P a+0.0264495 B C r+0.0050366 C a p F$

The results presented in Table 2 broadly confirm that financial innovation play an important role in affecting both gross savings and gross domestic savings. The estimations show that higher financial innovation leads to higher savings, therefore confirming the "liberalization of financial market" hypothesis. The effect of financial acces is captured by the number of ATMs and the number branches of banks. The results in the first model show that an increase in branches of banks per $1,000 \mathrm{~km}^{2}$ contribute to lower gross savings; and higher ATMs per 1,000 km contributes to higher savings. In addition, ATMs per 100,000 adults were found to decrease gross savings while branches of banks per 100,000 adults were found to increase gross domestic savings. These results suggests the great importance of effective distribution of financial access. These results might support the "diminishing marginal utility" effect of financial access after some break even point. The effect of financial stability is captured by the net interest margin and banking crisis dummy variable. The net interest margin has a negative effect on savings in both models. This result suggests that widening interest margin put a pressure on interest rates which would lead to diminishing savings. As expected, banking crisis also influence savings, and this impact is significant and positive. These results suggests that people hoarding funds with expectations of financial turmoils. 
On the macroeconomic level, the results show that an increase in capital formation contribute to higher gross savings and gross domestic savings thus validating the strong relationship between the macroeconomic factors. We therefrore use capital formation as a proxy for explanatory variable.

\section{CONCLUSION}

In recent years many banks in higher and upper income countries experienced a rapid growth in financial innovation and financial access. It has been long debated by policy makers that one of the important implications of financial deregulation is an increase in openness which it turn lead to higher financial access and innovation. The fast increase in financial innovation and access not only broaden the banks' operations but also mobilize savings which lead to more efficient resource allocation. This paper assesses these feedback effects and identifies financial innovation among the main determinants of the savings over time and across twenty upper income and high income countries using a fixed panel estimation technique. The paper finds that the level of financial innovation and financial access are important parameters affecting both gross savings and gross domestic savings. The empirical results show that higher financial innovation lead to higher savings, therefore confirming the "liberalization of financial market" hypothesis. Moreover, the results also show that financial instability positively influence savings and suggest that people hoarding funds with expectations of financial crisis. The paper also finds that both gross savings and gross domestic savings are sensitive to number of financial services such as ATMs per and branches of banks. These results suggests that effective distribution of financial access is of great significance as after some point the increasing number of financial services might diminish marginal utility. There is merit to strengthen supervision on the number of financial services to prevent a sharp buildup of inactive technology.

\section{REFERENCES}

Analytical Business Enterprise Research and Development Database (ANBERD), (Online), Access date: March 01, 2017, http://www.oecd.org/

Beck, Chen T., Lin C., \& Song Frank M. 2012, “Financial Innovation: The Bright and the Dark Sides", HKIMR Working Paper 05/2012

Hausman, J. A. 1978, "Specification tests in econometrics. Econometrica”, Journal of the Econometric Society, 1251-1271.

Hannig, A. and Jansen, S. 2010, “Financial Inclusion and Financial Stability: Current Policy Issues”, ADBI Working Paper No. 259, December 21.

Honohan, P. 2006, "Household Financial Assets in the Process of Development", Policy Research Working Paper; No. 3965. World Bank, Washington

Kıyılar, M. \& Akkaya, M. 2016. Davranışsal Finans. Literatür Yayınları, İstanbul, 2016

Laderman, Elizabeth S. 1990. "The Public Policy Implications of State Laws Pertaining to Automated Teller Machines," Economic Review, Federal Reserve Bank of San Francisco, Winter, 43-58.

Lerner, J. 2002, "Where Does State Street Lead? A First Look at Finance Patents, 1971- 2000," Journal of Finance, 57, p. 901-930.

Saldanli, A., Seker, M., 2013, "Finansal Gelişim Endeksi: Türkiye'deki illerin finansal gelişim seviyelerinin ölçülebilmesi için bir yaklasim": "Financial Development Index: An Approach to measurement of levels of Turkey's provinces financial development". World of Accounting Science. 15, 3, 17-38, Sept. 2013. Issn: 1302258x.

Shaw, E. 2002, Financial Deepening in Economic Development, Oxford University Press, London, 10-11

Tatoglu Yerdelen F. 2013. Panel Veri Ekonometrisi, Beta Yayınları, 2.Baskı, Ekim, ISBN 978-605-333-003-5

Valverde Carbó S., Del Paso Lopez R. and Fernández Rodríguez F. 2011, “Financial Innovations in Banking: Impact On Regional Growth", Regional Studies, 41:3, 311-326. 